\title{
Comparative Analysis of the Physicochemical Characteristics, Phytochemical Components and Fatty Acid Profile of Avocado Pear (Persea Americana L) Pulp and Seed Oil
}

\author{
O. M. Akusu, P. C. Obinna-Echem, P. C. Opurum and B. S. Chibor
}

\section{ABSTRACT}

\begin{abstract}
The physiochemical properties, phytochemical content, and fatty acid profile of Avocado pear (Persea americana) pulp and seeds oils were investigated. The pulp oil was extracted using the hot water flotation method while the seed oil was extracted by the soxhlet extraction method. Extracted oils were analyzed. The pulp oil was emerald green while the seed oil was brownish red in colour. Pulp oil has significantly higher blue (27B) on Lovibond scale. The oil yield, smoke point and flash point of the pulp oil were $28.26 \%$, $171.00{ }^{\circ} \mathrm{C}$ and $201.67{ }^{\circ} \mathrm{C}$ respectively. Which were higher than $13.64 \%$, 100.00 and $130.66{ }^{\circ} \mathrm{C}$ seen in the seed oil. Iodine value, FFA, peroxide value and saponification value of the pulp oil were respectively $50.70 \mathrm{~g} / 100 \mathrm{~g}$, $0.53 \%, 1.10 \mathrm{mEq} / \mathrm{kg}$ and $218.66 \mathrm{mgKOH} / \mathrm{g}$ while those of the seed oil were $40.68 \mathrm{~g} / 100 \mathrm{~g}, 2.85 \%, 2.16 \mathrm{mEq} / \mathrm{kg}$ and $198.31 \mathrm{mgKOH} / \mathrm{g}$ respectively. Saponins, alkaloid, phenol, tannin, and oxalate content of the seed oil were significantly higher than those of the pulp oil, with respective values of 12.23, 1.06, 5.06, 3.05 and $10.07 \mathrm{mg} / 100 \mathrm{~g}$. Flavonoid was however higher in the pulp oil, at $6.20 \mathrm{mg} / 100 \mathrm{~g}$. avocado pulp oil contained $43.23 \%$ oleic acid, $19.78 \%$ linoleic acid. It contains only $35.31 \%$ total saturated fatty acids. The seed oil was shown to contain $55 \%$ palmitic acid, as the predominant saturated fatty acid and contained a total of $69 \%$ saturated fatty acids. It is recommended that avocado seed oil be refined before use for culinary purposes.
\end{abstract}

Keywords: Avocado Pear Oil, Physical, Phytochemical, Fatty Acid Profile.

\author{
Published Online: January 9, 2021 \\ ISSN: $2684-1827$ \\ DOI: $10.24018 /$ ejfood.2021.3.1.212 \\ O. M. Akusu * \\ Department of Food Science and \\ Technology, Rivers State University, \\ Nigeria. \\ (e-mail: akusu.monday@yahoo.com) \\ P. C. Obinna-Echem \\ Department of Food Science and \\ Technology, Rivers State University, \\ Nigeria. \\ P. C. Opurum \\ Department of Food Science and \\ Technology, Rivers State University, \\ Nigeria. \\ B. S. Chibor \\ Department of Food Science and \\ Technology, Rivers State University, \\ Nigeria.
}

*Corresponding Author

\section{INTRODUCTION}

Avocado pear (Persea Americana) is well known in the tropical world and the species belongs to the family lauraceae [1]. It is a climacteric fruit, which implies that it matures on, but ripens off the tree [2]. Its pulp contains high amount of fats and oils, protein and fibre. Its possession of high amount of digestible oil and low sugar content makes avocado pear a rich source of energy and an essential component of diabetics' diets [3]. About $65 \%$ of the pear is the pulp, the seed is $20 \%$ and the skin $15 \%$ [4]. High consumption of Persea americana is reported to have beneficial effects on blood serum cholesterol levels [5]. About 75\% of an avocado's calories comes from fat, most of which is monounsaturated fat. The pear is rich in vitamin $\mathrm{B}, \mathrm{E}$ and $\mathrm{K}$ [5], [6]. Fatty acid content includes linoleic, oleic, palmitic, stearic, linolenic, and myristic acids [7]. Presence of diseasecuring phytochemicals may be responsible for numerous health benefits of plants [8]-[11]. It also contains important lipid-soluble antioxidants and phytochemicals such as carotenoids, chlorophylls, polyphenols, tocopherols, and phytosterols [12], [13]. The monounsaturated fatty acids present in the pulp are believed to modify the fatty acid contents in cardiac and renal membranes and enhance the absorption of $\alpha / \beta$ carotene and lutein [14]. The carotenoid content has been reported to play significant role in cancer risk reduction [15].

The seed is a by-product usually not utilized. it is discarded at some point of processing the pulp. This may be an ecological problem [16]. But is possibly will be beneficial to industries as a supply of bioactive compounds [3]. Several biological actions of the seed have been reported anti-oxidant, antihypertensive, fungicidal and hypolipidemic, [17]. Moreover, quite a few studies have also been alerted on the assessment of acute toxicity of the fruit and leaves [18], [19]. The seeds are rich in tannins and carotenoids [15]. Currently, the seed represents an under-utilized resource and a waste issue for avocado processors. The avocado pear seeds are discarded in the majority of countries, although in some countries such as Niger Republic, it is consumed [20]. This waste may represent an ecological or human contaminant.

Avocado pear is inexpensive. The pulp oil does not need modification before use, unlike the other oils used in margarine formulation and spreads formulation [16]. Avocado pear is rich in unsaturated fatty acids with natural occurring antioxidants and bioactives. There is the need for enhanced utilization of avocado pulp and seed oils, for value added products, not only to reduce waste but also for the 
economic benefits of the country. Thus, the aim of this study was to evaluate the physicochemical properties, phytochemical components and fatty acid profile of avocado pulp and seed oils, to provide basis for its possible dietary and industrial uses.

\section{MATERIALS AND METHODS}

Mature and good quality fruits from the Avocado pear (Persea americana) were purchased from the fruit market in Port Harcourt, Nigeria.

\section{A. Seed Flour Preparation and Oil Extraction}

The fruit were cleaned, cut open with a knife to remove seeds (de-stoning). The seeds were sliced and then crushed by means of a grater and oven dried at $60{ }^{\circ} \mathrm{C}$ for $24 \mathrm{~h}$ [21], ground using a laboratory mill (model MXAC2105, Panasonic, Japan). Oil was extracted from the seed flour using the bulk extraction process [22].

\section{B. Pulp Oil Extraction (Hot Water Floatation Method)}

The pulp was mashed using a ceramic mortar and pestle and drying the pulp in an air oven at $50{ }^{\circ} \mathrm{C}$ for $48 \mathrm{~h}$. The dried sample was then made into a paste thereafter released into boiling water and allowed to cook for $6 \mathrm{~h}$. The Oil that floated to the surface was collected and transferred and drained to remove water. The oil was finally dried in an air- oven for 2 $\mathrm{h}$ at $50{ }^{\circ} \mathrm{C}$ before storing in a vessel for further analysis [23].

\section{Physicochemical Properties}

Physicochemical properties including acid value, iodine value, free fatty acids, peroxide value, Saponification value, Unsaponifiable matter, melting point, Refractive index and density were determined by the method of AOAC [22].

\section{Determination of Saponin Content}

The method of Obadoni, and Ochuko [24] was used to determine the saponin content of the oil. $5 \mathrm{~g}$ of the oil extract was introduced into a conical flask, and $25 \mathrm{ml}$ of $20 \%$ aqueous ethanol was added. The sample was heated over a water bath for 1 hour with continuous stirring at about $55^{\circ} \mathrm{C}$. The mixture was moved into a $250 \mathrm{ml}$ separator funnel and $5 \mathrm{ml}$ of diethyl ether was added and shaken vigorously. The aqueous layer was recovered. $15 \mathrm{ml}$ of n-butanol was added, and then $2.5 \mathrm{ml}$ of $5 \%$ aqueous sodium chloride was added. The resulting solution was heated to evaporate to constant weight. All samples were analyzed in triplicates.

$$
\text { Saponins }(\mathrm{mg} / \mathrm{g})=\frac{\text { Weight of residue }}{\text { Weight of sample }}
$$

\section{E. Determination of Alkaloid Content}

The method described by Harborne [25] was used. Five $(5 \mathrm{~g})$ of the oil extracts was measured into $250 \mathrm{ml}$ beaker and $100 \mathrm{ml}$ of $20 \%$ acetic acid/ethanol added and allowed to stand for 4 hours. The mixture after 4 hours was stirred vigorously and filtered through whatman (No. 1) filter paper. The filtrate was thickened for 20 mins. Precipitation occurred as $20 \mathrm{~cm}^{3}$ concentrated ammonium hydroxide $\left(\mathrm{NH}_{4} \mathrm{OH}\right)$ was introduced drop wise to the extract until the precipitation was completed. The whole solution was allowed to settle and the precipitate was collected by filtration and weighed. All samples were analyzed in triplicates. The difference between the weights was evaluated as the quantity of alkaloid present in the sample:

where,

$$
\% \text { Alkaloid }=\frac{\mathrm{w} 2-\mathrm{w} 1 \mathrm{X} 100}{\text { Weight of sample }}
$$

$\mathrm{W} 1$ = weight of empty filter paper.

$\mathrm{W} 2=$ weight of precipitate.

\section{F. Determination of Tannin}

The method described by Nwokonkwo [26] was used. Five $(5 \mathrm{~g})$ of each sample was weighed into a $250 \mathrm{~cm}^{3}$ beaker to which was introduced $50 \mathrm{~cm}^{3}$ distilled water and shaken vigorously for 1hour. The mixture was filtered into a $1000 \mathrm{~cm}^{3}$ volumetric flask and made up. $5 \mathrm{~cm}^{3}$ of the filtrate was taken and mixed with $2 \mathrm{~cm}^{3} 0.1 \mathrm{M}$ iron (III) chloride in 0.Ml HCL and $0.008 \mathrm{M}$ potassium ferrocyanide. The absorbance was measured at $760 \mathrm{~nm}$ wavelength using a spectrophotometer, using the reagent blank to calibrate the spectrophotometer.

Concentration of sample $=$ $=\frac{\text { Absorbance of sample } \times \text { Concentration of Standard }}{\text { Absorbance of standard }}$

\section{G. Determination of Flavonoid}

The method described by Oyetayo [27] was followed. Five $\left(5 \mathrm{~g}\right.$ ) of each sample was added to $50 \mathrm{~cm}^{3}$ of $2 \mathrm{M}$ solutions of hydrochloric acid and refluxed for $30 \mathrm{mins}$. This was cooled and filtered. $5 \mathrm{~cm}^{3}$ of the filtrate was treated with $5 \mathrm{~cm}^{3}$ ethyl acetate; a precipitate formed and was recovered by filtration and put into pre-weighed filter paper. Each sample was dried at $100{ }^{\circ} \mathrm{C}$ for 30 minutes and cooled in desiccators and reweighed. The percentage flavonoid was calculated using the equation.

$$
\% \text { flavonoid }=\frac{\mathrm{W} 2-\mathrm{W} 1 \mathrm{X} 100}{\mathrm{~W} 3}
$$

where,

$\mathrm{W} 1$ = weight of empty filter paper.

$\mathrm{W} 2$ = weight of precipitate.

W3 = weight of crude sample.

\section{H. Total Phenol Content}

Total phenolic content was determined calorimetrically using Folin-Ciocalteau reagent (Phosphomolybdate and phosphotungstate). about $0.4 \mathrm{~g}$ extract in $20 \mathrm{ml}$ of acidified methanol $\left(1 \% \mathrm{HCl}\right.$ in methanol) for 1 hour at $25^{\circ} \mathrm{C}$, vortex mixing at 5-minute intervals were centrifuged (Model 1020 D.E, UK) for 10 minutes at $1200 \mathrm{rpm}$. Two replicate extract supernatants $(0.5 \mathrm{ml})$ mixed in $2.5 \mathrm{ml}$ of Folin-Ciocalteau reagent and allowed to stand at $25^{\circ} \mathrm{C}$ for $8 \mathrm{~min}$. Then $7.5 \mathrm{ml}$ of $20 \%$ sodium bicarbonate solution added to the mixture. Absorbance was measured After $2 \mathrm{~h}$ at $25^{\circ} \mathrm{C}$ at $765 \mathrm{~nm}$ using a UV-visible spectrophotometer. A standard curve was prepared using various concentration of tannic acid and the results were reported as $\mathrm{mg}$ tannic acid equivalents/g of sample 


\section{Oxalate Content}

Using standard method [22]. $1 \mathrm{~g}$ was measured into $100 \mathrm{ml}$ conical flask. $75 \mathrm{ml}$ of $3 \mathrm{M} \mathrm{H}_{2} \mathrm{SO} 4$ added and carefully stirred intermittently with a magnetic stirrer for about 1 hour and then filtered using Whatman No.1 filter paper. The sample filtrate (25 $\mathrm{ml}$ extract) was collected, and filtrate $(25 \mathrm{ml}$ extract) was titrated against hot $\left(80-90{ }^{\circ} \mathrm{C}\right) 0.1 \mathrm{~N} \mathrm{KMnO} 4$ solution to a faint pink colour that persisted for at least $30 \mathrm{~s}$.

Calculation:

\section{$1 \mathrm{ml} 0.1 \mathrm{~N} \mathrm{KMnO} 4=0.006303 \mathrm{~g}$ oxalate}

\section{J. Fatty Acid Profile}

The individual fatty acids in the oils were determine using the AOAC [22] methods as described by Chibor et al. [21]. Fatty acid methyl esters (FAME) were prepared from the extracted oils. In $50 \mathrm{ml}$ round bottom flasks, $50 \mathrm{mg}$ of each sample was kept in separate flasks and $3 \mathrm{ml}$ of sodium methylate solution $(0.5 \mathrm{~mol} / \mathrm{l}$ of methanolic solution of $\mathrm{NaOH})$ was added. The reaction medium was refluxed for 10 minutes; $3 \mathrm{ml}$ of acetyl chloride was added; mixture was refluxed again for 10 minutes and then cooled to ambient temperature; $8 \mathrm{ml}$ hexane and $10 \mathrm{ml}$ of distilled water was added and allowed to stand for 5 minutes to establish a two phase solution. The upper organic phase was recovered into a vial for GC analysis, using Agilent 7890A, coupled with flame-ionization detector (FID).

\section{K. Statistical Analysis}

All the analyses were carried out in triplicate. Data obtained were subjected to Analysis of Variance (ANOVA); differences between means were evaluated using Turkey's multiple comparison tests with $95 \%$ confidence level. The statistical package in Minitab software version 16 was used.

\section{RESULTS AND DISCUSSION}

\section{A. Physical Properties of avocado Pear Pulp and Seed Oil}

Result for the physicochemical properties of avocado pear pulp and seed oil as shown in Table 1 indicates that, the pulp oil was emerald green while the seed oil was brownish red in colour. Pulp oil has significantly higher blue (27B) on Lovibond scale probably due to presence of chlorophyll, carotenoids and other pigments [28].

Percentage Oil yield from the pear pulp (28.26\%) was significantly $(\mathrm{P}<0.05)$ higher than oil from seed $(13.64 \%)$. Oil yield from the seed was higher than $6.9,8.10$ and $9.22 \%$ reported earlier by Maduka [29], Adaramola [3] and Oluwole [5], respectively. As noted by earlier researchers, seeds must contain oil yield greater than $17 \%$ to be considered as oil seeds [30]. Therefore, avocado pear seed is not recommended for the purpose of edible oil generation and large scale industrial application due to low oil yield. However, variation in oil yield may be due to the differences in species of plant, cultivation climate, ripening stage, the harvesting time of the seeds and the extraction method [29] as well as solvent used [31]. According to Bwade [32], the oil content of agricultural products such as fruits and seeds determines largely whether or not oil can be industrially processed from them.
The density of the pulp and seed oils were respectively 0.90 and $0.92 \mathrm{~g} / \mathrm{ml}$, with seed oil given significantly $(\mathrm{P}<0.05)$ higher value. Density of the pulp oil compares with $0.903 \mathrm{~g} / \mathrm{ml}$ reported by Orhevba and Jinad [2] and slightly higher than $0.89 \mathrm{~g} / \mathrm{ml}$ reported by Akusu and Wodu [33] for African pear pulp oil, while $0.92 \mathrm{~g} / \mathrm{ml}$ seen in the seed oil is comparable with 0.91 and $0.912 \mathrm{~g} / \mathrm{ml}$ reported by Adaramola, et al. [3] and Dagde [34] respectively. The result implied that avocado pulp and seed oils are less dense than water and could therefore be useful in culinary creaming and cosmetic purposes. The density gives information on the weight of the fat and the solid content at a specified temperature [35].

Refractive index (RI) of the avocado oils was 1.32 and 1.45 for pulp and seed oil respectively, with seed oil given significantly $(\mathrm{P}<0.05)$ higher value. This showed that avocado seed oil contains more polyunsaturated fatty acids than the pulp oil. Refractive index of oil increases with increasing chain length and also with number of double bonds present in the oil [35]. RI also depend on the degree of unsaturation and the degree of conjugation of the oil [36]. RI of 1.32 for the pulp oil was however higher than 1.231 reported earlier by Orhevba and Jinadu [2] and lower than 1.467 reported for African pear pulp oil [33]. RI of 1.45 the seed oil agreed with 1.47 reported for corn and soybean oil [37].

The melting point, smoke point and flash point of the avocado oils were 15.50 and $12.33 ; 171.00$ and 100.00; and 201.67 and $130.66{ }^{\circ} \mathrm{C}$ for pulp and seed oil respectively. The slip melting point is an indication of the temperature at which the fat softens or becomes sufficiently fluid to slip or flow [21]. The lower melting point of avocado pulp and seed oils $\left(15.50\right.$ and $12.33{ }^{\circ} \mathrm{C}$ ) indicates that they have less resistance to shear stress, this makes them suitable for inclusion in table or bakery margarine blend to enhance plasticity [35]. Melting point of $15.50{ }^{\circ} \mathrm{C}$ for pulp oil agreed with $15.00{ }^{\circ} \mathrm{C}$ reported earlier by Nwaokobia et al [1]. The smoke point of avocado pulp oil was significantly $(\mathrm{P}<0.05)$ higher than the seed oil, making the pulp oil suitable for high temperature frying, as smoke point indicates the temperature limit up to which that cooking oil can be used [38]. Smoke point (SP) correlates with the amount of free fatty acid in the oil, SP does tend to increase as the free fatty acid content decreases [21]. Flash point of 201.67 and $130.66^{\circ} \mathrm{C}$ for avocado pulp and seed oils present pulp oil with significantly higher value, making it suitable for high temperature frying operations.

\begin{tabular}{ccc} 
TABLE 1: PHYSICAL PROPERTIES OF AVOCADO PEAR PULP AND SEED OIL \\
\hline Parameters & APO & ASO \\
\hline Colour (descriptive) & emerald green & Brownish red \\
Colour (Lovibond) & 20.5Y 10. R & $19.66 \mathrm{Y} 10.8 \mathrm{R}, 0.6 \mathrm{~B}$ \\
Oil Yield $(\%)$ & $27 \mathrm{~B}$ & $13.64^{\mathrm{b}} \pm 0.011$ \\
Density $(\mathrm{g} / \mathrm{ml})$ & $28.26^{\mathrm{a}} \pm 0.002$ & $0.92^{\mathrm{a}} \pm 0.001$ \\
Refractive index & $0.90^{\mathrm{b}} \pm 0.004$ & $1.45^{\mathrm{a}} \pm 0.001$ \\
Melting Point $\left({ }^{\circ} \mathrm{C}\right)$ & $1.32^{\mathrm{b}} \pm 0.000$ & $12.33^{\mathrm{b}} \pm 0.600$ \\
Smoke point $\left({ }^{\circ} \mathrm{C}\right)$ & $15.50 \mathrm{a} \pm 0.010$ & $100.00^{\mathrm{b}} \pm 1.100$ \\
Flash point $\left({ }^{\circ} \mathrm{C}\right)$ & $171.00^{\mathrm{a}} \pm 1.002$ & $130.66^{\mathrm{b}} \pm 0.577$ \\
\hline
\end{tabular}

Values are means \pm standard deviation of triplicate samples.

Mean values bearing different superscripts in the same row differ significantly $(\mathrm{p}<0.05)$.

Key: $\mathrm{APO}=$ Avocado pulp oil, $\mathrm{ASO}=$ Avocado seed oil. 


\section{B. Chemical Properties of avocado Pear Pulp and Seed Oil}

Results for chemical properties of avocado pulp and seed oils as presented in Table 2, showed $\mathrm{pH}$ value ranging from $5.90-6.16$, with the pulp oil given significantly $(\mathrm{P}<0.05)$ higher value of 6.16. This value was slightly higher than 5.7 $\mathrm{pH}$ reported earlier by Orhevba and Jinadu [2]. While $\mathrm{pH}$ of 5.90 seen in the seed oil was lower than 6.2 reported by Maduka et al [29]. Result indicates that seed oil is slightly acidic than the pulp oil. Difference in $\mathrm{pH}$ as reported by earlier researchers is probably due to varietal differences.

The moisture contents were respectively 1.25 and $0.98 \%$ for pulp and seed oil, higher moisture in pulp oil was probably due to extraction method and degree of drying. Moisture in both oils were beyond the standard limit of $0.2 \%$ [39]. High moisture content of a product enhances oil acidification and peroxidation processes. It is a determinant of water activity of many foods [40].

Percentage free fatty acid (FFA) showed the seed oil given significantly $(\mathrm{P}<0.05)$ higher value of 2.85 , which is slightly above the standard maximum limit of $2.00 \%$ [39], [41]. Avocado seed oil thus need some level of refining for use as edible oil. FFA of the seed oil compared with $2.26 \%$ reported by Adaramola et al [3], but lower than $5.89 \%$ reported by Maduka et al [29]. Also lower in comparison with 4.88, 2.45, 2.38 and $38.85 \%$ reported for Citrullus vulgaris, soursop, watermelon and breadfruit seed oils respectively [42], [43] and [44]. This value is however higher than that reported for Carica papaya seed oil (1.27\%) as well as Telfairia occidentalis $(0.89 \%)$ [45], [35]. FFA of the pulp oil was $0.53 \%$, which falls within the standard recommended range [39], [41], such that avocado pulp oil can be used for culinary purposes without further refining. Low FFA content of the oil shows that the oil has low susceptibility to enzymatic hydrolysis [46].

Iodine value (IV) of the pulp and seed oils $(50.70 \mathrm{~g} / 100 \mathrm{~g})$ was significantly $(\mathrm{P}<0.05)$ higher than that of the seed oil $(40.68 \mathrm{~g} / 100 \mathrm{~g})$. IV of the seed oils was higher than $23.50 \mathrm{~g} / 100 \mathrm{~g}$ reported by Adaramala et al [3]. Iodine value (IV) of the pulp oil was also higher than $37.26 \mathrm{~g} / 100 \mathrm{~g}$ reported earlier by Orhevba and Jinadu [2], but lower than $88.00 \mathrm{~g} / 100 \mathrm{~g}$ presented by Indriyani et al [47]. This differences are probably due to varietal difference. Iodine value is a simple chemical constant used to measure unsaturation or the average number of double bonds in an oil sample. It is defined as the number of grams of iodine that could be added to $100 \mathrm{~g}$ of oil [35], [48].

The peroxide value (PV) was respectively 1.16 and $2.16 \mathrm{mEq} / \mathrm{kg}$, for pulp and seed oil. Seed oil gave significantly $(\mathrm{P}<0.05)$ higher value, however, both oil falls within the recommended standard of $\leq 10 \mathrm{mEq} / \mathrm{kg}$ [39], [41]. Peroxide value is an important tool in measuring the oxidative rancidity and the degree of deterioration of lipids. PV of 2.16 $\mathrm{mEq} / \mathrm{kg}$ in this work agreed with $2.40 \mathrm{mEq} / \mathrm{kg}$ reported by Adaramola et al [3], but lower than 43.00 and $14.85 \mathrm{mEq} / \mathrm{kg}$ reported by Maduka et al [2] and Indriyani et al [47], respectively for avocado seed oil.

Saponification value and unsaponifiable matter content of the pulp and seed oils were respectively 218.66 and $198.31 \mathrm{mgKOH} / \mathrm{g}$, and 1.11 and $1.32 \%$. High saponification value is an indication of oil suitability for industrial use [35]
[33]. High saponification value is suitable for soaps and shampoo, pharmaceutical, and food processing [49], low saponification value is also suitable for food processing [33]. Saponification value is a measure of the alkali-groups in fats and oil and is defined as the mg $\mathrm{KOH}$ needed to saponify $1 \mathrm{~g}$ of oil [36]. It is a measure of all the saponifiable fatty acids (including the esters) present in oil [49]. unsaponifiable matter content of both pulp and seed oils were relatively high when compared to values from other oil seeds. Shea butter, fluted pumpkin seed oil, ground nut oil and soybean oil had USM content ranging from $0.2-0.95 \%$ [35], [49]. The high USM content of avocado seed oil showed that the oil is rich in desirable bioactive components such as; antiinflammatory, antioxidants and antimicrobial substances including the fat soluble vitamins.

TABLE 2: Chemical Properties Of Avocado PeAR PulP AND SEed OIL

\begin{tabular}{ccc}
\hline Parameters & APO & ASO \\
\hline $\mathrm{pH}$ & $6.16^{\mathrm{a}} \pm 0.150$ & $5.9^{\mathrm{b}} \pm 0.010$ \\
Moisture content $(\%)$ & $1.25^{\mathrm{a}} 0.010$ & $0.98^{\mathrm{b}} \pm 0.010$ \\
Free Fatty Acid $(\%)$ & $0.53^{\mathrm{b}} \pm 0.005$ & $2.85^{\mathrm{a}} \pm 0.010$ \\
Iodine value $(\mathrm{g} / 100 \mathrm{~g})$ & $50.70^{\mathrm{a}} \pm 0.010$ & $40.68^{\mathrm{b}} \pm 0.015$ \\
Peroxide Value $(\mathrm{mEq} / \mathrm{kg})$ & $1.16^{\mathrm{b}} \pm 0.010$ & $2.16^{\mathrm{a}} \pm 0.020$ \\
Saponification Value & $218.66^{\mathrm{a}} \pm 0.611$ & $198.31^{\mathrm{b}} \pm 0.175$ \\
(mgKOH/g) & $1.11^{\mathrm{b}} \pm 0.010$ & $1.31^{\mathrm{a}} \pm 0.010$ \\
Unsaponifiable Matter $(\%)$ &
\end{tabular}

Values are means \pm standard deviation of triplicate samples.

Mean values bearing different superscripts in the same row differ significantly $(\mathrm{p}<0.05)$.

Key: $\mathrm{APO}=$ Avocado pulp oil, $\mathrm{ASO}=$ Avocado seed oil.

\section{Phytochemical Component of Avocado Pulp and Seed Oil}

Result for the phytochemical properties of avocado pulp and seed oil (Table 3) showed that saponins and alkaloid content of the seed oil were significantly higher, with values of 12.23 and $1.06 \mathrm{mg} / 100 \mathrm{~g}$, respectively. The seed oil contained more saponins than the pulp with $(2.137 \mathrm{mg} / 100 \mathrm{~g})$. Saponin content of the pulp and seed oils were lower than $0.14 \mathrm{mg} / \mathrm{g}$ and $19.21 \mathrm{mg} / \mathrm{g}$ reported by Arukwe et al [50]. Saponins are consumed in many common foods and beverages including: oats, peanuts, tea and beer. Saponins have many health benefits. Studies have illustrated the beneficial effects on blood cholesterol levels, cancer, bone health and stimulation of the immune system [2].

Flavonoid contents of the oils were respectively 6.20 and $2.10 \mathrm{mg} / 100 \mathrm{~g}$, for pulp and seed oil, with pulp oil given significantly $(\mathrm{P}<0.05)$ higher value. They are known to have antioxidant effects and have been shown to restrain the initiation, promotion, and progression of tumors [51], reduction of coronary heart disease has been reported to be associated with intake of flavonoid [52]. Total phenol contents were 2.45 and 5.16 for pulp and seed oils, respectively. These values were lower than the maximum phenolic content of $18.546 \mathrm{mg} / \mathrm{g}$ ) found in Fuente Seeds extracted at $50{ }^{\circ} \mathrm{C}$ [16]. Phenolic compounds act as antioxidants in oil [15]. The possession of flavonoid and phenolic compounds implies that avocado seed oil does not only have nutritional and industrial values, but may also possess some medicinal potential [3].

Tannin and total oxalate component of the avocado oils ranged from 1.13-3.05 mg/100 $\mathrm{g}$ and 4.07-10.07 mg/100 g for pulp and seed oil respectively. With seed oil given 
significantly $(\mathrm{P}<0.05)$ higher values. Tannin in the pulp oil is below lethal dosage [53]. However, Suvanto et al [54] gave $0.15-0.20 \%$ as recommended safe level of tannin, thus seed oil requires certain level of refining. Total oxalate content of the oils was much higher than $2.79 \mathrm{mg} / 100 \mathrm{~g}$ reported by Degnon et al [55]. However, the oxalate levels in the pulp and seed oil samples were below the lethal dosage of soluble oxalate intake $2-5 \mathrm{~g}$ [56].

TABLE 3: PhytochemicAl COMPONENT (mg / 100g) OF AVOCADo PUlP

\begin{tabular}{ccc}
\multicolumn{3}{c}{ AND SEED OIL } \\
\hline Phytochemicals & APO & ASO \\
\hline Saponins & $2.14^{\mathrm{b}} \pm 0.015$ & $12.23^{\mathrm{a}} \pm 0.153$ \\
Alkaloid & $0.70^{\mathrm{b}} \pm 0.100$ & $1.06^{\mathrm{a}} \pm 0.010$ \\
Flavonoids & $6.20^{\mathrm{a}} \pm 2298$ & $2.10^{\mathrm{b}} \pm 0.100$ \\
Total Phenols & $2.45^{\mathrm{b}} \pm 0.012$ & $5.06^{\mathrm{a}} \pm 0.035$ \\
Tannin & $1.13^{\mathrm{b}} \pm 0.015$ & $3.05^{\mathrm{a}} \pm 0.0153$ \\
Total Oxalates & $4.07^{\mathrm{b}} \pm 0.015$ & $10.07^{\mathrm{a}} \pm 0.015$ \\
\hline
\end{tabular}

Values are means \pm standard deviation of triplicate samples.

Mean values bearing different superscripts in the same row differ significantly $(\mathrm{p}<0.05)$.

Key: $\mathrm{APO}=$ Avocado pulp oil, $\mathrm{ASO}=$ Avocado seed oil .

\section{Fatty Acid Profile of Avocado Pulp and Seed Oil}

From the result in Table 4, avocado pulp oil contained $43.23 \%$ oleic acid, which is the predominant monounsaturated fatty acid present, it is also rich in polyunsaturated fatty acid (omega-6); with $19.78 \%$ linoleic acid. It contains only $35.31 \%$ total saturated fatty acids. These qualities present avocado pulp oil as safe and nutritionally healthy for human consumption. Unsaturated fatty acids are healthier fatty acids that prevent cardiovascular diseases. Avocado seed oil was shown to contain 55\% palmitic acid, as the predominant saturated fatty acid and contained a total of $69 \%$ saturated fatty acids. Ecosadienoic (EDE) acid, an omega- 6 polyunsaturated fatty acid was higher in the seed oil $(2.45 \%)$ than pulp oil $(0.12 \%)$. High content of polyunsaturated fatty acid (C18:2 and C20:2) in avocado pulp and seed oil make it a rich source of essential fatty acid [21], [35], with great potentials to enhance the nutritional value of its food products. (Fig. 1 and 2).

\begin{tabular}{ccc}
\multicolumn{2}{c}{ TABLE 4: FATTY ACID PROFILE OF AVOCADO PULP AND SEED OIL } \\
\cline { 2 - 3 } Fatty acids & Percentage composition \\
\hline Myristic (C14: 0) & APO & ASO \\
Palmitic acid (C16: 0) & 1.68 & - \\
Palmitic (C16: 1) & 12.6 & 55 \\
Stearic acid (C18: 0) & 1.25 & - \\
Oleic acid (C18: 1$)$ & 19.78 & 3.05 \\
Linoleic acid (18: 2$)$ & 43.23 & 20.67 \\
Arachidic (C20: 0$)$ & 19.78 & 5.25 \\
Eicosenoic (C20: 1$)$ & 1.25 & 10.95 \\
Ecosadienoic (C20: 2$)$ & 0.12 & 2.58 \\
\hline
\end{tabular}

Key: $\mathrm{APO}=$ Avocado pulp oil, $\mathrm{ASO}=\mathrm{Avocado}$ seed oil.

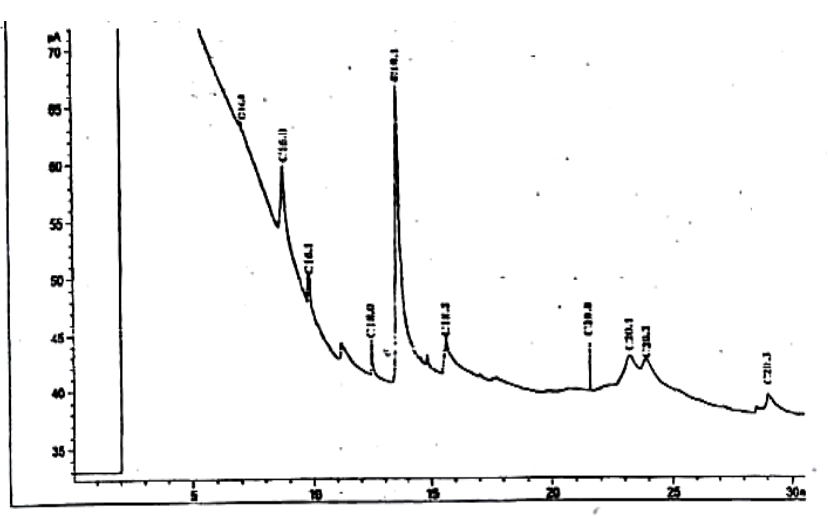

Fig 1. Fatty acid GC Chromatogram of Avocado Pear Pulp oil.

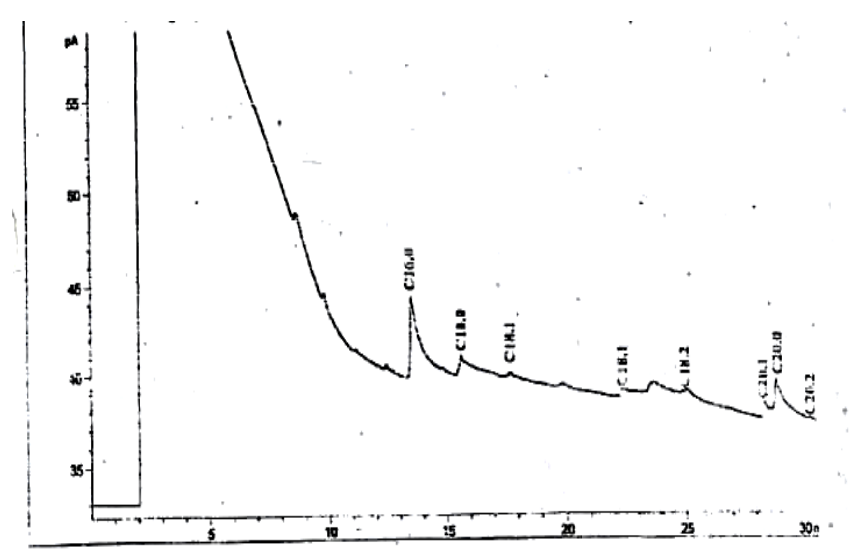

Fig 2. Fatty acid GC Chromatogram of Avocado Seed.

\section{CONCLUSION}

Avocado pulp gave oil yield of $28.26 \%$, indicating that it is a good source of vegetable oil. High smoke point of avocado pulp oil indicates that it can be used for a wide range of culinary application. Low FFA and peroxide value of the pulp oil gives it better oxidative stability. Relatively higher percentage free fatty acid, saponins and oxalate content of avocado seed oil implies that it needs further refining, for use as food. Presence of Flavonoids and phenolic compounds in avocado pulp and seed oils suggest that they are good source of useful bioactive and functional ingredients for food formulations. This also enhance their antioxidant abilities. High content of polyunsaturated fatty acid in avocado pulp oil makes it a rich source of essential fatty acid, safe and nutritionally healthy for human consumption.

\section{REFERENCES}

[1] Nwaokobia1, K., Ogboru, R.O and Idibie, C.A. (2018). Extraction of edible oil from the pulp of Persea americana (Mill) using cold process method. World News of Natural Science WNOFNS, 17, 130-140.

[2] Orhevba, B.A. and Jinadu, A.O. (2011). Determination of PhysicoChemical Properties and Nutritional Contents Of Avocado Pear (Persea Americana M.). Academic Research International, 1,3,372380.

[3] Adaramola, B., Onigbinde, A. and Shokunbi, O. (2016). Physiochemical properties and antioxidant potential of Persea Americana seed oil. Chemistry International, 2(3) 168-175.

[4] Nayak, BS, Rafu SS, Chatapti, RAV. (2008) Wound healing activity of persea Americana (Avocado) fruit: a potential study on rats. Journal of wound care, 17:123-126.

[5] Oluwole, S., Yusuf, K., Fajana, O., Olaniyan, D. (2013). Qualitative Studies on Proximate Analysis and Characterization of Oil from Persea Americana (Avocado Pear). Journal of Natural Sciences Research 3(2), 68-73. 
[6] Maitera, O.N., Osemeahon, S.A., Barnabas, H.L. (2014). Proximate and Elemental Analysis of Avocado Fruit obtained from Taraba State, Nigeria. Indian Journal of Science and Technology 2(2), 6773.

[7] Dreher, M.L., Davenport., A.J. (2013). Hass Avocado composition and potential health benefits. Cri. Rev. food Sci. Nutr. 53, 738-750.

[8] Elsayed, E., Lobna, S., 2013. Hypolipidemic activities of hydroalcoholic extract of avocado fruit on high cholesterol fed diet in rats and its antioxidant effect in vitro. Journal of American Science 9(12), 337-343.

[9] Ashraf, M.W., Bilal, M., Iqbal, M. (2015). Antiglycation activity of vegetables aqueous and methanolic extracts. Current Science Perspectives 1, 12-15.

[10] Asif, M., 2016. A review on recent advances and potential pharmacological activities of versatile chalchone molecule. Chemistry International 2, 1-18.

[11] Hussain, F., Shahid, M., Javed, K., 2016. Antioxidant, antiglycation and alpha Amylase inhibitory activities of Cassia absus seeds. Current Science Perspectives 2, 5-9.

[12] Pieterse, Z. (2003). Avocados (monounsaturated fatty acids), weight loss and serum lipids. Energy, 26:65-71.

[13] Boyadzhie, S.S., Georgieva, S.S. and Angelov, G. (2018). Optimization of the extraction of natural antioxidants from avocado seeds. Bulgarian Chemical Communications, 50:80-84.

[14] Solazer, M.J., El-Hafidi, M., Pastelin, C., Ramirez-Ortega, M.C. and Sanchez-Mendoza. (2005). Effect of an avocado oil-rich diet over an angiotensin 11-induced blood pressure response. Journal of Ethnopharmacol, 98(3):335-338.

[15] Lu QY, Arteaga JR, Zhang Q, Huerta S, Go VL, Heber D (2005) Inhibition of prostate cancer cell growth by an avocado extract: role of lipid-soluble bioactive substances. J Nutr Biochem 16(1): 23-30.

[16] Ortiz, M.A., Dorantes, A.I., Gallnedez, M.J. and Cardenas, S.E. (2004). Effect of a novel oil extraction method on avocado (Persea Americana Mill) pulp microstructure. Plant foods for human nutrition, 59(1):11-14.

[17] Rodríguez-Carpena, J.G., Morcuende, D., Estévez, M. (2011). Avocado by-products as inhibitors of color deterioration and lipid and protein oxidation in raw porcine patties subjected to chilled storage. Meat Science 89, 166-173.

[18] Anaka ON, Ozolua R.I, and Okpo S.O, (2000) Effect of The Aqueous Sead Extract of Persea Americana Mill (lauracea) on the blood pressure of Spraque-dawley rats. African Journal. Pharmacist Pharmacology, 9, 3: 485-90.

[19] Tango, J. S. T.; Carvalho, C. R. L.; Soares, N. B. (2004.) Physical and chemical characterization of avocado fruits aiming its potencial for oil extraction. Brasileira de Fruticultura, 26, 1,

[20] Gupta, S.K., Singhal, P. and Sing, A. (2018). Nutritional and Pharmaceutical Benefits of Avocado Plant. Journal Advance Research, 9 (2):4-11.

[21] Chibor B. S., Kiin-Kabari D. B and Eke-Ejiofor J. (2018). Comparative Assessment of the Physicochemical Properties and Fatty Acid Profile of Fluted Pumpkin Seed Oil with Some Commercial Vegetable Oils in Rivers State, Nigeria. Research Journal of Food and Nutrition, 2(2): 32-40.

[22] AOAC. (2012). Official Methods of Analysis of the Association of Analytical Chemists. 19th Edition. Washington, DC, USA.

[23] Rosenthal, A., Pyle, D.I. and Niranjan, K. (1996). Aqueous and Enzymatic Processes for edible oil extraction. Enzyme Microbiology and Microbial Technology, 19, 402-420.

[24] Obadoni, B.O and Ochuko, P.O. (2002). Phytochemical studies and comparative efficacy of the crude extracts of some haemostatic plantsin Edo and Delta State of Nigeria. Global Journal of Pure and Applied Science, 8(2). DOI:10,4314/gjpas.v8i2.16033.

[25] Harborne, J.B. (1998). Phytochemical Methods: A Guide to Modern Techniques of Plant Analysis, $3^{\text {rd }}$ ed. Springer, Delhi.

[26] Nwokonkwo, D.C. (2014). Phytochemical Study and anti-bacterial activities of the seed extract of Dacryode edulis (African Native Pear). American Journal of Science and Industrial Research, 5 (1):712.

[27] Oyetayo, F.L and Ojo, B.A. (2012). Food value and phytochemical composition of Luffa xylindrica seed flour. American Journal of Biochemistry, 2 (6):98-103.

[28] Flores, M., Saravia, C., Vergara, C.E., Avila, F., Valdés, H. and Ortiz-Viedma, J. (2019). Avocado Oil: Characteristics, Properties, and Applications. Molecules, 24, 2172; doi:10.3390/molecules24112172.

[29] Maduka Tochukwu DO*, Ikpa Chiyere BC and Kalu Georgina. (2020). Physicochemical Characterization and Assessment of Bioactive Chemical Compounds of Persea Americana (Avocado) Seed. Journal of Natural and Ayurvedic Medicine, 4(1): 000229.
[30] Akinoso R., Raji A.O., 2010. Optimization of Oil Extraction from Locust Beans using Response Surface Methodology. European Journal of Lipid science and Technology 113(2), 245-252.

[31] Nnaji JC, Okereke OB (2016) Proximate composition and physicochemical properties of three avocados. (Persea americana) Varieties in Umuahia, Nigeria, Journal of Applied Chemical Science International, 5(4): 195-200.

[32] Bwade, K. E., Aliyu, B., Kwaji, A. M. (2013). Physicochemical properties of pumpkin seed oil relevant to biodiesel production and other industrial applications. International Journal of Engineering, Business and Enterprise Applications 4(1), 72-78.

[33] Akusu, O. M. and Wordu, G. O. (2019). Physicochemical properties and fatty acid profile of Allanblackia seed oil and African pear pulp oils. International Journal of Biotechnology and Food Science, 7(2), 14-22.

[34] Dagde KK (2019) Extraction of Vegetable Oil from Avocado Seeds for Production of Biodiesel, J Appl Sci Environ Manage 23(2): 215221.

[35] Chibor, B.S., Kiin-Kabari, D.B. and Ejiofor, J. (2017). Physicochemical Properties and Fatty Acid Profile of Shea Butter and Fluted Pumpkin Seed Oil, a Suitable Blend in Bakery Fat Production. International Journal of Nutrition and Food Sciences. 6(3), 122-128.

[36] Shahidi, F. (2005). Quality Assurance of Fats and oils. In: Bailey's Industrial oil and fats products, Shahidi, F. (Ed). 6A Edn. John Wily and Sons Inc., USA.

[37] Sodeke, V.A., (2005). Extraction of Oil from Water Melon Seed and Analysis (2005). Quarterly Research Service:25-30.

[38] Thomes, A. (2002). Fats and fatty oils, Ullman's Encyclopedia of Industrial Chemistry, Weinheim Wiley-VCH ISBN 3:527- 30673.

[39] CODEX (2011). CODEX Alimentairus Commission Standard for Fats and Oil Derived from Edible Fats and Oils, FAO Corporate Document, CODEX STAN 32. Retrieved from https://www.fao.org/docrep/004/y2774e06. 10th July, 2019.

[40] Andzouana, M., Mombouli, J.B. (2012) Assessment of the Chemical and Phytochemical Constituents of the Leaves of a Wild VegetableOchthocharis dicellandroides (Gilg). Pakistan Journal of Nutrition 11 (1): 94-99.

[41] Nigerian Industrial Standards (NIS). (1992). Standard Organization of Nigeria, Standard for Edible Vegetable Oil. Lagos, Nigeria: Essential Communications Ltd.

[42] Zaharaddeen, N.G., Galadima, A., Abdulfatai A.S. 2014. Mineral Composition, Physicochemical. Properties and Fatty Acids Profile of Citrullus Vulgaris Seed Oil. Research Journal of Chemical Sciences, 4(6), 54-57.

[43] Navaratne, S.B., Subasinghe, D.J.S. (2013). Determination of fatty acid profile and physicochemical properties of Watermelon and Soursop seed oils. European International Journal of Applied Science and Technology 1(4), 26-32.

[44] Bwai, M. D., Adedirin, O., Akanji, F. T., Muhammad, K. J., Idoko, O. and Useh, M. U. (2013). Physicochemical Properties, Fatty Acids Profiles and Antioxidant Properties of Seed Oil of Breadfruit (Treculia africana). International Journal of Research in Pharmaceutical Sciences 3(3), 44-54.

[45] Cassia, R.M., Mieko, K., Neuza, J., 2011. Characterization of a high oleic oil extracted from papaya (Carica papaya L.) seeds. Ciência e Tecnologia de Alimentos 31(4), 929-934.

[46] Kiin-Kabari, D.B., Ejiofor, J. and Chibor, B.S. (2018). Changes in Physicochemical Characteristics and Microbiological Quality of Bakery Shortening Formulated with Shea Butter and Fluted Pumpkin Seed Oil During Storage. International Journal of Food Science and Biotechnology, 3(3): 89-94.

[47] Indriyani, L., Rohman, A. and Riyanto, S. (2016). Physico-Chemical Characterization of Avocado (Persea americana Mill.) Oil from Three Indonesian Avocado Cultivars. Research Journal of Medicinal Plant 10 (1): 67-78.

[48] Ononogbu, I. C. (2002). Lipid in Human Existence. Ap Express, Nsukka pp. 1-80.

[49] Aremu, M.O., Ibrahim, H., and Bamidele, T.O. (2015). Physicochemical Characteristics of the Oils Extracted from Some Nigerian Plant Foods. Chemical and Process Engineering Research. 32, 22-25.

[50] Arukwe, U., Amadi, B.A.,Duru, M. K.C., Agomuo,E.N., Adindu, E. A.,Odika, P.C.,Lele,K.C., Egejuru, L., and Anudike, J.(2012)Chemical Composition Of PerseaAmericana Leaf, Fruit And Seed. IJRRAS, 11,2. www.arpapress.com.

[51] Gertz, C., Klostermann, S. And Kochhar, S.P. (2000). Testing and Comparing oxidativestability of vegetable oils andfats at frying temperature. Eur. J. Lipid Sci. Technol.102,543-551. 
European Journal of Agriculture and Food Sciences www.ejfood.org

[52] Ghosh, P.K., Chatterjee, D. And Bhattacharjee, P. (2012). Alternative methods of frying and antioxidant stabilityin soybean oil. Adv. J. Food Sci. Technol. 4, 26-33.

[53] Schiavone A, Guo, K, Tassone S. (2008). Effects of a natural extract of chestnut wood on digestibility, performance traits, and nitrogen balance of broiler chicks. Poultry science, 87 (3): 521-7.

[54] Suvanto J, Nohynek L, Seppänen-Laakso T, Rischer H, Salminen JP, Puupponen-Pimiä R. (2017) Variability in the production oftannins and other polyphenols in cell cultures of 12 Nordic plantspecies. Planta, 246(2): 227-241.

[55] Degnon MRG, Adjou ES, Noudogbessi JP, et al. Investigationon nutritional potential of soursop (Annonamuricata L.) from Benin for its use as food supplement against protein-energy deficiency. IJB. 2013; 3(6): 135-144.

[56] Ezeagu, I.E. (1997). Nutrient composition and protein quality of seeds of some uncultivated plants in Nigeria. Ph. D Thesis, Department of Animal Science, Univerisity of Ibadan, Ibadan, Nigeria. 